\title{
TINDAK TUTUR LOKUSI PEDAGANG DAN PEMBELI DI PASAR SUDI MAMPIR BANJARMASIN
}

\section{Heppy Lismayanti dan Dana Aswadi}

Pendidikan Bahasa dan Sastra Indonesia STKIP PGRI Banjarmasin

Jalan Sultan Adam, Komplek H. Iyus, No. 18 RT.23 Banjarmasin,

Kalimantan Selatan. Kode pos 70121

email: Heppylismayanti@stkipbjm.ac.id

\begin{abstract}
Abstrak
Penelitian inifokus pada bagaimana Citra Pahlawan dalam Sastra Lisan Datu Aling di Bahasa merupakan sebuah sarana untuk menuangkan segala ide serta pikiran. Dengan bahasa, seseorang mampu mengungkapkan berbagai pikiran. Tindak tutur lokusi sebagai salah satu kajian untuk mengungkap hubungan bahasa dengan masyarakat menjadi salah satu hal yang menarik untuk diamati. Sebagai tempat, pasar Sudi Mampir menjadi tempat yang penuh dengan transaksi jual beli. Artinya, tindak tutur terjadi di tempat tersebut.

Pendekatan yang digunakan adalah pendekatan kualitatif yang melalui tiga tahapan, yaitu tahap deskripsi, tahap reduksi, dan tahap seleksi. Metode yang digunakan dalam penelitian ini adalah metode simak libat cakap, metode simak bebas libat cakap serta metode wawancara. Subjek yang dilakukan dalam penelitian ini adalah masyarakat tutur, yaitu penjual dan pembeli. Sumber data dalam penelitian ini merupakan sumber tidak tertulis, yakni jenis data primer yang berasal dari hasil pengamatan langsung. Teknik pengumpulan data yang digunakan adalah teknik observasi lapangan. Dan teknik analisis data yang digunakan adalah teknik deskriptif. Hasilnya adalah ditemukannya jenis tindak tutur lokusi yang ditemukan, yaitu pertanyaan, pernyataan, dan perintah.
\end{abstract}

\section{Kata kunci: tindak tutur, lokusi}

\section{Pendahuluan}

Bahasa merupakan sebuah sarana untuk menuangkan segala ide serta pikiran. Dengan bahasa, seseorang mampu mengungkapkan berbagai pikiran. Bahkan, seseorang juga mengungkapkan perasaannya dengan bahasa., baik senang, gembira, bahkan sedih. Hal itu diungkapkan dengan bahasa. Bahasa menjadi perantara yang menghubungkan antara konteks satu dengan konteks lainnya. Dalam setiap komunikasi manusia saling menyampaikan informasi yang dapat berupa pikiran, gagasan, maksud, perasaaan maupun emosi secara langsung. Artinya, setiap komunikasi yang ada, bahasa selalu digunakan sebagai alat untuk menyampaikannya. Jadi, bahasa menghubungkan antara pemberi pesan dengan penerima pesan agar bisa saling memahami satu dengan yang lainnya. Penggunaan bahasa ini tidak terkecuali dilakukan dalam sebuah masyarakat. Masyarakat menjadi sentral penggunaan bahasa. Dalam kajiannya, penghubungan antara bahasa dengan masyarakat disebut dengan sosiolinguistik. 
Sosiolinguistik merupakan kajian yang menghubungkan antara lingusitik dengan sosiologi. Linguistik adalah bahasa. Bahasa ini dikaji berdasarkan kajian yang dilekatkan padanya. Bahkan, bahasa ini sangat menarik untuk diamati karena keuniversalannya dalam segala hal yang mengikutinya. Dengan linguistik ini maka segala bahasa dan fenomenanya bisa diamati, terutama dengan menggunakan kajian yang dihubungkan dengan sosiologi. Sosiologi disini berarti masyarakat. Masyarakat sebagai pemakai bahasa memiliki andil yang besar terhadap perkembangannya. Semakin berkembang masyarakatnya sebagai pemakai bahasa maka semakin berkembang kebahasaannya.

Komunikasi selalu terjadi di masyarakat. Bagaimanapun tingkatan masyarakatnya dan dimanapun berada maka suatu masyarakat tidak akan terlepas dari bahasa. Bahasa dijadikan sebagai alat komunikasi. Dengan bahasa, masyarakat akan saling berhubungan serta berkomunikasi. Hal ini menandakan bahwa linguistik dan sosiologi tidak dapat dipisahkan.

Belajar bahasa tidak cukup hanya mempelajari pengetahuan tentang bahasa, tetapi lebih dari itu bagaimana bahasa itu digunakan. Bidang bahasa yang mengkaji bahasa beserta konteksnya disebut pragmatik. Pragmatik mempelajari maksud tuturan seseorang yang tersirat dibalik tuturannya. Pragmatik mengkaji tentang bagaimana orang-orang tahu lebih banyak hal yang dikomunikasikan daripada yang dikatakan.

Pasar Sudi Mampir merupakan pusat perbelanjaan grosir dan eceran pakaian yang terbesar di Banjarmasin. Di pasar ini selalu terjadi interaksi antara penjual dan pembeli. Bahkan, pasar ini juga merupakan pasar yang menarik untuk diamati karena pembelinya bukan hanya berasal dari Banjarmasin tetapi juga berasal dari luar Banjarmasin, seperti Tapin, Hulu Sungai Selatan, bahkan sampai luar kalimantan selatan seperti, Kalimantan Tengah. Pembeli dan penjual ini saling bertemu untuk membahas barang yang akan dijual/ dibeli.

Tindak tutur selalu terjadi dalam komunikasi penjaul dan pembeli di pasar terapung. Misalnya saja.

Pembeli : : "Ini barapa haraganya cil" (Ini harganya berapa bu?)

Penjual : "Nang mana?" (Yang mana?)

Pembeli : : "Nang ini? (Yang ini!)

Penjual : : "Itu salusinnya 350.000, kawa ai 3 haja, sama motif” (Itu satu lusinnya 350.000, bisa belinya 3 saja, sama motifnya)

Situasi tersebut di atas mengisyaratkan bahwa dalam transaksi jual beli yang ada di pasar Sudi Mampir terdapat sebuah tuturan. Tuturan tersebut diawali dengan sebuah pertanyaan pembeli terhadap harga barang, "Ini barapa haraganya cil" (Ini harganya berapa bu?). ini merupakan sebuah inisiasi komunikasi yang menggunakan bahasa sebagai pancingan jawaban si penjual. Kemudian, penjual pun menjawab pertanyaan itu dengan pertanyaan juga, "Nang mana?" (Yang mana?). Ini menandakan bahwa dalam setiap komunikasi antara penjual dan pembeli di pasar terdapat tindak tutur. Tindak tutur ini menarik untuk diamati karena setiap sangat berpengaruh terhadap komunikasi 
antara penutur dan lawan tutur dalam wacana sosiolinguistik dan pragmatik, atau yang kita kenal dengan sosiopragmatik. Tindak tutur komunikasi yang di bangun melalui pengkotruksian atas fakta dan peristiwa, merupakan hal yang biasa dilakukan manusia di dalam kehidupannya masingmasing. Dalam setiap komunikasi selalu melibatkan penutur dan lawan tutur. Peristiwa tindak tutur dalam wacana jual beli di pasar mempunyai peranan yang sangat penting, yaitu menyampaikan maksud dan tujuan berbagai pihak, penjual dan pembeli sama sama menggunakan bahasa sebagai sarana untuk menyampaikan maksud agar tercapai kesepakatan. Interaksi antara penjual dan pembeli di Pasar Tanjung pada waktu tertentu dengan menggunakan bahasa sebagai alat komunikasinya disebut dengan peristiwa tutur.

Tindak tutur merupakan gejala individual, bersifat psikologis, dan keberlangsungannya ditentukan oleh kemampuan bahasa si penutur dalam menghadapi situasi tertentu. Kalau dalam peristiwa tutur lebih dilihat pada tujuan peristiwanya, tetapi dalam tindak tutur lebih dilihat pada makna atau arti tindakan tuturannya. Tindak tutur dan peristiwa tutur merupakan dua gejala yang terdapat pada suatu proses komunikasi.

\section{Metode}

Pendekatan yang digunakan dalam penelitian ini adalah pendekatan kualitatif. Penelitian kualitatif di desain secara longgar, tidak ketat dan fleksibel. Langkah-langkah kerja penelitian kualitatif Menurut Sugiyono (2007 dalam Gunawan 2015:107) terdapat tiga tahap utama dalam penelitian kualitatif, yaitu (1) tahap deskripsi atau tahap orientasi (2) tahap reduksi, dan (3) tahap seleksi. Pengumpulan dari kedua jenis data diatas dilakukan dengan tiga metode, yaitu metode simak libat cakap, dan simak bebas libat cakap yang dalam ilmu sosial setara dengan observasi berpatisipan (participant-observation) dan observasi tidak berpatisipan (nonparticipantobservation) serta metode wawancara menggunakan telepon seluler sebagai alat rekam. Data yang telah diperoleh terlebih dahulu diklasifikasikan sebelum dianalisis. Metode analisis data yang digunakan adalah metode deskriptif, metode komparatif, dan metode kontekstual.

\section{Hasil dan Pembahasan}

Wibowo (2015) menyebutkan tindak tutur komunikasi, yang dibangun melalui pengkotruksian atas fakta dan peristiwa, merupakan hal yang biasa dilakukan manusia di dalam kehidupannya masing-masing. Bahasa sebagai pembentuk wacana pada hakikatnya adalah cerminan suatu nilai kehidupan yang terkonteks pada masyarakat pengguna bahasa itu. Dengan demikian, keliru jika ungkapan bahasa dijadikan ajang konpirasi dalam hal politik pemaknaan oleh subjeksubjek penyajinya demi menancapkan makna-makna tertentu dibenak orang lain, tanpa orang lain menolaknya. Pandangan John Austin tentang bahasa telah menimbulkan pengaruh yang besar di 
bidang filsafat maupun linguistik. John Austin adalah orang yang pertama mengungkapkan bahwa bahasa dapat digunakan untuk melakukan tindakan (Cummings, 2007). Chaer dan Agustina (2010) mendefinisikan tindak tutur sebagai gejala individual yang bersifat psikologis dan keberlangsungannya ditentukan oleh kemampuan bahasa penutur dalam menghadapi situasi tertentu. Tindak tutur ini lebih menitikberatkan pada makna atau arti tindak dalam suatu tuturan. Tindak tutur dapat berwujud suatu pertanyaan, perintah, maupun pernyataan.

Suwito; Rohmadi (2004) menjelaskan jika peristiwa tutur (speech event) merupakan gejala sosial dan terdapat interaksi antara penutur dalam situasi dan tempat tertentu, maka tindak tutur (speech acts) lebih cenderung sebagai gejala individual, bersifat psikologis dan ditentukan oleh kemampuan bahasa penutur dalam menghadapi situasi tertentu. Lebih lanjut dijelaskan bahwa jika dalam peristiwa tutur orang menitikberatkan pada tujuan peristiwanya, maka dalam tindak tutur orang lebih memperhatikan makna atau arti tindak dalam tuturan itu.

Tindak lokusi adalah tindak tutur yang menyatakan sesuatu. Tindak tutur ini sering disebut sebagai The Act of Saying Something. Menurut Rahardi (2009) tindak tutur lokusi adalah tindak tutur dengan kata, frasa, dan kalimat, sesuai dengan yang dikandung makna kata, frasa, dan kalimat itu sendiri. Tindak lokusi adalah tindak tutur yang relatif paling mudah untuk diidentifikasikan karena cenderung dapat dilakukan tanpa menyertakan konteks tuturan yang tercakup dalam situasi tutur. Chaer dan Agustina (2010) menyatakan berdasarkan kategori gramatikal bentuk tindak tutur lokusi dibedakan menjadi tiga, yaitu bentuk pernyataan (deklaratif) adalah bentuk pernyataan berfungsi hanya untuk memberitahukan sesuatu kepada orang lain sehingga diharapkan pendengar untuk menaruh perhatian. Kedua, bentuk pertanyaan (integrotif) adalah bentuk pertanyaan berfungsi untuk menanyakan sesuatu sehingga pendengar diharapkan memberikan jawaban atas pertanyaan yang diajukan oleh penutur. Ketiga, bentuk perintah (imperatif) adalah bentuk perintah memiliki maksud agar pendengar memberi tanggapan berupa tindakan atau perbuatan yang diminta. Peristiwa terjadinya atau berlangsungnya interaksi linguistik dalam satu bentuk ujaran atau lebih yang dua pihak yaitu penutur dan lawan tutur, dengan satu pokok tuturan di dalam waktu, tempat, dan situasi tertentu disebut dengan peristiwa tutur (Chaer dan Agustina, 2010).

Hymes (dalam Chaer dan Agustina, 2010:48) menyebutkan bahwa ada delapan komponen yang harus dipenuhi dalam peristiwa tindak tutur yang bila huruf-huruf pertamanya dirangkai menjadi akronim SPEAKING. SPEAKING menurut Hymes sebagai berikut.

$\boldsymbol{S} \quad=$ Situasi (act situation), mencakup latar dan suasana

$\boldsymbol{P} \quad=$ Partisipant, mencakup penutur, pengirim, pendengar, dan penerima.

$\boldsymbol{E} \quad=$ End (tujuan), mencakup bentuk pesan dan isi pesan.

$\boldsymbol{A}=$ Act Sequence (urutan tindak), mencakup bentuk pesan dan isi pesan

$\boldsymbol{K}=$ Key ( kunci) 
I = Instrumentalities (peranti, perabotan), mencakup saluran dan bentuk tutur.

$N=$ Norms (norma), mencakup norma interaksi dan norma interpretasi

$\boldsymbol{G} \quad=$ Genre

Komponen SPEAKING ini digunakan sebagai komponen mengetahui tindak tutur lokusi di pasar Sudi Mampir. Bentuk tindak tutur lokusi antara penjual dan pembeli di pasar Sudi Mampir Banjarmasin sebagai berikut.

a. Tindak Tutur Lokusi bentuk pertanyaan

Tindak tutor lokusi bentuk pertanyaan merupakan tindak tutur yang dituturkan oleh penutur kepada mitra tuturnya berupa pertanyaan. Lihat kutipan berikut.

Penjual : "Cari apa ding?" (Apa yang dicari, dik)

Pembeli : "Balalihat dahulu, boleh ai lu". (Melihat dulu, boleh)

Penjual : "boleh ai, lihati ja. Nang kiapa dicari?" (Boleh saja, lihat saja. Pakaian seperti apa yang dicari)

Pembeli : "Nang ini barapaan cil" (Ini berapa harganya bu)

Penjual : "Ukuran ikam barapa" (Ukuran kamu berapa)

Pembeli : "27 cil ai" (ukuran 27 bu)

Penjual : "Nang ini nah, cobai dahulu" (Yang ini dicoba dulu)

Pembeli : "Pas haja cil ai, warnanya nang lain ini apa ja cil" (ukurannya tepat. Warna yang lain ada bu)

Penjual : "Ada ai, ini nah, ada nang habang, habuk, lawan coklat" (Ada, ini ada warna merah, abu, dan cokelat)

pembeli : "nang coklat ni bungas cil, ambilakan cil. barapa haraganya?" (Yang cokelat cantik, ambilkan bu, berapa harganya?)

penjual : "120, kawa ja kurang" (120 ribu, bisa kurang)

pembeli : "60 nah cil" (60 ribu bu!?)

penjual : "Kada sampai modalnya ding ai, ayu haja nah, 100 gasan ikam" (modalnya tidak sampai dik, ayo saja, untuk kamu 100 ribu)

pembeli : "ayu haja nah cil, 80 sudah" (Ayo saja bu, 80 ribu jadi)

penjual : “Ayu ja, tambahi 5, jadi 85 nah” (Ayo, tambah 5 ribu, jadi 85 ribu)

pembeli : "Kada, saitu haja" (Tidak, begitu saja)

penjual : "Iya, 80" (Baik, 80 ribu)

pembeli : "Tukar dulu cil lah, barelaan" (Tukar dulu bu, minta rela)

penjual : "Jual, sama-sama" (Jual, sama-sama)

Kutipan di atas menunjukkan bahwa terdapat beberapa kata yang mengandung tindak tutur lokusi dengan bentuk pertanyaan. Bentuk pertanyaan ini menandakan bahwa tindak tutur tidak terlepas dari sebuah komunuikasi yang mengandung pertanyaan. Pada konteks Cari apa ding? (Apa yang dicari, dik?) yang diinisiasi oleh penjual menunjukkan bahwa pertanyaan ini ditujukan kepada dik atau adik. Adik ini mengarah pada seorang calon pembeli. Penjual menawarkan barangnya sehingga tindak tutur penjual tersebut muncul secara alami. Cari apa ding? (Apa yang dicari, dik?). Si penjual bertanyaan kepada calon pembelinya berkenaan apa yang dicari. 
Komunikasi yang mengandung pertanyaan ini kemudian dilanjutkan pada konteks selanjutnya yaitu "boleh ai, lihati ja. Nang kiapa dicari?" (Boleh saja, lihat saja. Pakaian seperti apa yang dicari). Pada konteks tersebut, penjual kembali bertanya kepada pembeli, Nang kiapa dicari? (Pakaian seperti apa yang dicari). Kata Nang ini merujuk pada pakaian yang dicari oleh pembeli. Karena mencari pakaian yang diinginkan, pembeli mencarinya. Kemudian, muncullah pertanyaan tersebut.

Konteks pertanyaan ini juga muncul dalam beberapa percakapan seperti, : nang ini barapaan cil (Ini berapa harganya bu), ukuran ikam barapa (Ukuran kamu berapa), pas haja cil ai, warnanya nang lain ini apa ja cil? (ukurannya tepat. Warna yang lain ada bu?), dan nang coklat ni bungas cil, barapa haraganya? (Yang cokelat cantik, berapa harganya?). Hal ini menunjukkan bahwa dalam setiap transaksi yang dilakukan oleh penjual dan pembeli di pasar terdapat sebuah tindak tutur yang berupa pertanyaan. Pertanyaan ini digunakan untuk mengetahui lebih mendalam lagi berkenaan dengan benda atau hal yang ingin diketahuinya lagi. Jawaban dari sebuah pertanyaan akan memberikan kepuasan kepada pelanggan (pembeli) sehingga pembeli pun akan senang dan merasa dilayani oleh penjual. Pertanyaan yang terdapat diatas mengungkapkan ketidaktahuan pembeli terhadap barang yang diinginkannya. Ia pun mencari tahu tentang benda yang diinginkannya berupa pertanyaan, misalnya pada konteks warnanya nang lain ini apa ja cil (warna yang lain ada bu). Konteks ini mengisyaratkan ketidaktahuan pembeli berkenaan warna pakaian yang akan dibelinya sehingga memunculkan sebuah pertanyaan berkenaan dengan warna apa saja yang ada. Bukan hanya pembeli, penjual pun juga menggunakan bentuk pertanyaaan ini untuk mengetahui benda apa saja yang dibeli oleh pembeli. Misalnya saja pada konteks cari apa ding? (Apa yang dicari, dik). Konteks ini menunjukkan ketidakatahuan penjual berkenaan dengan barang apa yang dicari oleh pembeli. Untuk mengetahui serta meyakinkan bahwa orang yang datang itu ingin membeli benda apa, maka penjual pun memancing tentang apa saja yang diinginkan oleh penjual. Oleh karena itu, dengan jawaban tadi maka penjual pun akhirnya mengetahui benda yang diinginkan oleh pembeli.

b. Tindak Tutur Lokusi bentuk pernyataan

Lokusi bentuk pernyataan merupakan tindak tutur yang mengisyaratkan proposisi yang menyatakan sesuatu. Ada suatu hal yang ingin ditekankan oleh salah satu pihak. Dalam jual beli yang ada di pasar Sudi Mampir juga terdapat sebuah pernyataan yang ingin menekankan sesuatu, artinya memberikan informasi berupa penekanan, baik dari pihak penjual maupun pembeli. Lihat kutipan berikut. 
Penjual : "Cari apa ding?" (Apa yang dicari, dik)

Pembeli : "Balalihat dahulu, boleh ai lu". (Melihat dulu, boleh)

Kutipan di atas sangat jelas sekali terdapat penekanan oleh si pembeli. Pembeli ingin menginformasikan alasan dia berada di toko si penjual. Hal tersebut tampak pada konteks "balalihat dahulu" (Melihat dulu). Konteks balalihat dahulu memberikan informasi kepada si penjual bahwa pembeli pertama-tama ingin melihat dulu apa saja yang dijual oleh pembeli. Hal ini berupa tekanan satu tindakan menggunakan indera penglihatan oleh pembeli.

Dalam konteks yang lainnya, pembeli juga memberikan sebuah pernyataan kepada penjual. Lihat kutipan berikut.

Penjual : "Nang ini nah, cobai dahulu" (Yang ini dicoba dulu)

Pembeli : "Pas haja cil ai, warnanya nang lain ini apa ja cil" (ukurannya tepat. Warna yang lain ada bu)

kutipan di atas diawali dengan sebuah pertanyaan dari penjual yang mengetahui informasi berkenaan dengan pilihan pakaian yang diberikannya kepada pembeli. Kemudian, pembeli pun memberikan penekanan informasi berupa pernyataan "Pas haja cil ai" (Ukurannya tepat). Pembeli memberikan informasi kepada penjual bahwa ukuran yang diberikan itu tepat dan sesuai dengan ukuran badan si pembeli. Tepat ini mengisyaratkan bahwa apa yang dipilih tersebut sudah sesuai. Kesesuai ini memunculkan sebuah pernyataan pembeli sehingga diapiun menegaskan apa yang menurutnya sudah tepat.

Lihat kutipan berikut yang menyatakan warna.

Penjual : "Ada ai, ini nah, ada nang habang, habuk, lawan coklat" (Ada, ini ada warna merah, abu, dan cokelat)

pembeli : "nang coklat ni bungas cil, barapa haraganya?" (Yang cokelat cantik, berapa harganya?)

Pada kutipan di atas ini juga mengisyaratkan sebuah pernyataan yang berhubungan dengan warna. Pembeli menyatakan warna yang disukainya. Konteks "nang coklat ni bungas" (Yang cokelat cantik) menunjukkan bahwa pembeli ingin menyatakan bahwa warna tersebut disukainya. Hal ini dikarenakan pilihan warna yang diberikan oleh si penjual, kemudian pembeli pun melihat berbagai warnanya sehingga tertarik serta menyukainya warna cokelat. Pernyataan ini terjadi karena adanya sebuah penekanan yang dilakukan mitra tuturnya. Hal ini untuk menginformasikan kepada mitra tutur bahwa hal tersebut harus diperhatikan, sehingga fokus keduanya di sebuah pernyataan tersebut. Ketika sudah fokus terhadap pernyataan tersebut maka pembicaraan pun mengarah sesuai dengan pernyataan. 
c. Tindak Tutur Lokusi bentuk perintah

Tindak tutur perintah ini merupakan tindak tutur yang menyatakan seuatu kehendak dari lawan tuturnya dengan cara memerintah, baik oleh penjual ataupun pembeli. Lihat kutipan berikut.

Penjual : "Ada ai, ini nah, ada nang habang, habuk, lawan coklat" (Ada, ini ada warna merah, abu, dan cokelat)

pembeli : "nang coklat ni bungas cil, ambilakan cil. barapa haraganya?" (Yang cokelat cantik, ambilkan bu, berapa harganya?)

penjual : "120, kawa ja kurang” (120 ribu, bisa kurang)

kutipan di atas menunjukkan konteks perintah. Si pembeli memerintah kepada di penjual untuk mengambilkan benda/ barang yang diinginkannya. Hal ini tampak pada konteks ambilakan cil (ambilkan bu).

\section{Simpulan}

Tindak tutur merupakan gejala individual, bersifat psikologis, dan keberlangsungannya ditentukan oleh kemampuan bahasa si penutur dalam menghadapi situasi tertentu. Kalau dalam peristiwa tutur lebih dilihat pada tujuan peristiwanya, tetapi dalam tindak tutur lebih dilihat pada makna atau arti tindakan tuturannya. Tindak tutur dan peristiwa tutur merupakan dua gejala yang terdapat pada suatu proses komunikasi. Oleh karena itu, berdasarkan urain di atas dapat disimpulkan sebagai berikut.

a. Tindak tutur lokusi pedagang dan pembeli di pasar Sudi Mampir Banjarmasin memiliki bentuk pertanyaan,

b. Tindak tutur lokusi pedagang dan pembeli di pasar Sudi Mampir Banjarmasin memiliki bentuk pernyataan, dan

c. Tindak tutur lokusi pedagang dan pembeli di pasar Sudi Mampir Banjarmasin memiliki bentuk perintah.

\section{Daftar Pustaka}

Chaer, Abdul dan Agustina, Leonie. 2010. Sisiolingiustik Perkenalan Awal. Jakarta: PT Rineka Cipta.

Cummings, Louise. 2007. Pragmatik Sebuah Persektif Multidispliner. Yogyakarta: Pustaka Belajar.

Rahardi, Kunjana. 2008. Pragmatik Kesantunan Imperatif Bahasa Indonesia. Jakarta: Erlangga.

Rahardi, Kunjana. 2009. Sosiopragmatik. Yogyakarta: PT. Gelora Aksara Pratama.

Rohmadi, Muhammad. 2004. Pragmatik Teori dan Analisis. Yogyakarta: Lingkar Media. 
Rohmadi, Muhammad, Sadhono,Kundharu dan Hastuti Sri. 2013. Kajian Paragmatik Peran Konteks Sosial Dan Budaya Dalam Tindak Tutur Bahasa di Pacitan. Jakarta: Yuma Pustaka.

Wibowo, Wahyu. 2015. Konsep Tindak Tutur Komunikasi. Jakarta: PT Bumi Aksara.

Yule, George. 2014. Pragmatik. Yogyakarta: Pustaka Pelajar. 